\title{
Konsep Nasionalisme M. Quraish Shihab Dalam Tafsir
}

\section{Al-Mishbah}

\author{
Agus Mukmin, Lc. M. Hum \\ Dekan Fakultas Ekonomi dan Bisnis Islam IAI Al-Azhaar Lubuklinggau \\ Agusmukmin208@gmail.com
}

\begin{abstract}
Abstrak
Indonesia merupakan Negara besar yang majemuk baik suku, agama, ras, bahasa maupun budaya. Sehingga sangat rentan terhadap konflik dan perpecahan yang mengancam Negara Kesatuan Republik Indonesia (NKRI). Menurut penulis ada dua faktor yang dapat membahayakan sikap nasionalisme masyarakat Indonesia. Pertama factor internal, diantara contohnya adalah banyaknya kelompok separatis yang berusaha untuk memisahkan dari wilayah NKRI dan adanya aliran atau pemahamn yang tidak sepakat dan ingin merubah ideology Negara. Kedua, factor Eksternal, yakni perubahan tatanan dunia melalui arus globalisasi yang begitu pesat saat ini.

Agama Islam adalah agama yang ka<mil yang mengajarkan kepada umat manusia berbagai macam aspek kehidupan. Oleh karenanya, Islam tidak hanya mengajarkan pokok-pokok moral saja, tetapi juga mengajarkan masalah-masalah yang rinci tentang bagaimana manusia harus bertindak, baik dalam konteks hubungannya dengan Tuhan maupun dengan sesama, termasuk di dalamnya tata cara mengatur kehidupan masyarakat dalam sebuah negara.

Berangkat dari pernyataan ini, penulis tertarik melakukan penelitian terhadap konsep nasionalisme M. Quraish Shihab dalam tafsirnya al-Mishbah. Penelitian ini bertujuan untuk mengeksploitasi penafsiran M. Quraish Shihab tentang ayat-ayat yang memiliki spirit kebangsaan dan nasionalisme yang terdapat dalam tafsirnya. Pemilihan karya tafsir tersebut dikarenakan al-Mishbah merupakan sebuah tafsir yang popular dan banyak menjadi rujukan bagi masyarakat di Indonesia.
\end{abstract}


Penelitian ini merupakan penelitian kepustakaan (library research) yang bersifat kualitatif dengan menggunakan metode tafsir maudu'i (tematik) dengan pendekatan historis-sosiologis. Hasil penelitian ini menyebutkan bahwa pertama, konsep-konsep nasionalisme M.Quraish Shihab meliputi, mencintai negara, kesadaran adanya otoritas kepemimpinan, persatuan bangsa, menjaga stabilitas keamanan Negara, syuro, adanya kerjasama yang baik antara pemerintah dengan rakyatnya, menghargai dan menghormati perbedaan, dan adanya hukuman bagi perusuh dan pengacau negara.

\section{Kata Kunci: Nasionalisme, Tafsir Al-Mishbah}

\section{A. Pendahuluan}

Nasionalisme merupakan sebuah paham yang masih diperlukan peninjauan ulang atau penelitiannya yang lebih mendalam terhadap masyarakat yang menjadi bagian dari suatu bangsa dan Negara.Nasionalisme akan menjadi sebuah alat penggerak suatu Negara dalam menciptakan persatuan dan kesatuan bangsa manakala paham tersebut dapat dipahami dan dijalankan dengan sebaikbaiknya oleh seluruh lapisan masyarakat. Namun sebaliknya, jika masyarakat tidak memilikinya justru akan menjadi salah satu penyebab dari konflik, perselisihan bahkan perpecahan di Negara Kesatuan Republik Indonesia (NKRI).

Indonesia yang terdiri dari berbagai macam suku, bahasa, etnis, dan pulau, akan sangat rentan terjadi perselesihan dan konflik yang disebabkan oleh berbagai macam perbedaan tersebut. Dengan keadaan seperti ini, rasa nasionalisme merupakan salah satu sikap penting yang harus dimiliki oleh setiap lapisan masyarakat agar dengannya terciptalah suatu persatuan yang kokoh, cinta terhadap tanah air, dan saling menjaga demi keutuhan bangsanya. Namun, jika diteliti lagi fakta yang terjadi saat ini, ternyata rasa nasionalisme yang dimiliki masyarakat Indonesia belumlah tercipta dengan sempurna dan akan menjadi lebih buruk seandainya masyarakat tidak berusaha untuk memperbaikinya. 
Dalam laporan sindonews $2019^{113}$ dikatakan bahwa sejak kemerdekaan Indonesia tahun 1945 terdapat sejumlah gerakan separatis di Indonesia yang kehadirannya mengancam Nasionalisme Negara Kesatuan Republik Indonesia (NKRI), diantaranya Gerakan Aceh Merdeka (GAM) dan Organisasi Papua Merdeka (OPM). Selain itu adanya aliran-aliran keagamaan yang memimpikan diberlakukannya syariat Islam atau berdirinya negara (daulah) Islam. ${ }^{114}$ Fenomena keagamaan semacam ini, juga akan sangat santer mengikis budaya nasiolisme dalam diri masyarakata Indonesia jika tidak ditangani secara serius.

Selain dari sisi internal di atas ada juga factor eksternal yang menurut penulis sangat berpengaruh pada rasa nasionalisme masyarakat Indonesia yakni perubahan tatanan dunia melalui arus globalisasi yang begitu pesat saat ini. disaadari atau tidak, jika tidak dikelola dengan baik, globalisasi dapat mengikis semangat nasionalisme. Kecintaan pada negeri sendiri dapat berkurang akibat terbukanya arus informasi dan teknologi yang sangat sulit dihindari.

Secara tidak langsung, tatanan sistem sosial, agama, politik, ekonomi, dan budaya Indonesia, mendapatkan pengaruh dari luar, yang tidak semuanya bernilai positif, atau sesuai dengan harkat dan karakter masyarakat Indonesia sebagai sebuah bangsa. Tantangan globalisasi semacam inilah yang harus dijawab dengan melakukan internalisasi terhadap ideologi nasionalisme beserta perangkat norma termasuk norma agama yang mengokohkannya.

Berbicara mengenai Nasionalisme, maka akan banyak ditemukan definisi tentangnya. Salah satu di antaranya adalah memiliki arti kebangsaan, cinta akan

\footnotetext{
${ }^{113}$ Wahyono, "Sejumlah Gerakan Separatis di Indonesia" di akses pada tanggal 15 Desember 2020. https://nasional.sindonews.com/berita/1463855/14/sejumlah-gerakan-separatis-di-indonesia

${ }^{114}$ Segala bentuk peraturan, undang-undang, dan simbol-simbol kenegaraan, serta yang lainnya diaggap sebagai sistem $t a<g h u<t$ (syetan) yang tidak patut diikuti.Setidaknya terdapat tiga gerakan resmi yang bersifat terbuka memperjuangkan formalisasi syariat Islam, bahkan menginginkan Indonesia menjadi negara Islam.Pertama,Hizbut Tahrir Indonesia (HTI) merupakan organisasi yang secara terbuka memperjuangkan Indonesia menjadi negara Islam.Kedua, Majelis Mujahidin Indonesia (MMI), memperjuangkan berlakunya hukum Islam menjadi hukum nasional tanpa harus menjadikan Indonesia sebagai negara Islam.Ketiga, Komite Persiapan Pemberlakuan Syariat Islam (KPPSI) di Sulawesi Selatan yang memilih jalan realistis dengan memperjuangkan berlakunya syariat Islam melalui berbagai peraturan daerah. Lihat Masdar Farid Mas'udi, Syarah Konstitusi: UUD 1945 dalam Perspektif Islam, (Jakarta: Pustaka Alvabet 2010), hlm. xv
} 
tanah air atau faham kesatuan bangsa. ${ }^{115}$ Sehingga masyarakat yang memiliki rasa nasionalisme akan mencintai persatuan dan kesatuan bangsa.

Masyarakat Indonesia yang merupakan bangsa dengan penduduk mayoritas muslim, yang berpegang pada al-Qur'an di dalam segala hal dalam tatanan kehidupannya, selayaknya dalam permasalahan ini masyarakat Indonesia harus melihat bagaimana al-Quran berbicara tentang nasionalisme. Karena alQur'an diturunkan sebagai petunjuk umat manusia dalam menjalankan segala aktivitasnya di muka bumi ini, tak terkecuali dalam sebuah tatanan kenegaraan yang bertujuan untuk persatuan dan kesatuan sebuah Negara yang di dalamnya terjalin ketentraman dan keharmonisan di dalam masyarakat suatu bangsa tanpa adanya pengunggulan satu suku terhadap suku lain atau pengucilan bagian wilayah tertentu terhadap wilayah lain, karena keberagaman yang terdapat di dalam setiap Negara merupakan hasil dari ciptaan dan kehendakNya. Hal ini sebagaimana yang termaktub dalam al-Qur'an surat al-Hujarat ayat13 :

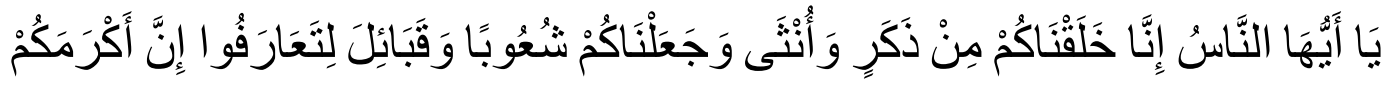

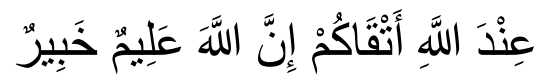

"Wahai manusia, kami menciptakanmu dari laki-laki dan perempuan, dan menjadikanmu berbangsa-bangsa dan bersuku-suku agar kamu saling mengenal. Sesungguhnya, yang paling mulia di antara kalian adalah yang paling bertaqwa.Sesungguhnya Allah Maha Mengetahui dan Maha Mengenal".

Berbicara mengenai al-Qur'an, banyak sekali hasil karya tulis yang telah membahas mengenai isi kandungan al-Qur'an. Hal ini menunjukan bahwa sebagai teks, al-Qur'an adalah sebuah bacaan yang masih sangat terbuka bagi para mufassir untuk terus berusaha mengeksploitasi makna dan rahasia al-Qur'an yang belum terungkap di dalamnya. M. Quraish Shihab yang merupakan salah satu dari sekian banyak para mufassir dan termasuk salah satu ulama paling berpengaruh di

${ }^{115}$ Pius A Partanto dan M. Dahlan al-Barry, Kamus Ilmiah Populer (Surabaya: Penerbit Arkola, 1994), hlm. 511. 
Indonesia pun demikian, lewat karya tafsirnya yang sangat fenomenal itu ia berusaha mengungkap rahasia dan kandungan yang terdapat di dalam al-Qur'an termasuk di dalamnya adalah konsep nasionalisme, meskipun tidak dijelaskan secara langsung dan terperinci.

Untuk mengetahui lebih mendalam mengenai nasionalisme, penulis memfokuskan penelitian ini pada kitab tafsir al-Mishbah. Al-Mishbah adalah sebuah kitab tafsir hasil karya M. Quraish Shihab. Dalam hal ini, ada beberapa alasan penulis lebih memilih kitab tafsir tersebut dibandingkan kitab-kitab tafsir lainnya, di antaranya adalah sebagai berikut: pertama: penulis kitab tafsir tersebut merupakan salah satu ulama yang sangat berpengaruh di Indonesia. Di samping itu, beliau adalah orang asli Indonesia, di mana, kondisi lingkungan dan budaya masyarakatnya sangat berperan besar dalam mempengaruhi pemikiran dan penafsirannya.Kedua, tafsir al-Mishbah merupakan karya tafsir al-Qur'an terbaru jika dibandingkan dengan kitab-kitab tafsir lainnya.Ketiga, kitab tafsir tersebut ditulis disaat masyarakat Indonesia dalam keadaan yang sangat memprihatinkan, di mana kemerosotan moral melanda hampir seluruh lapisan masyarakat, adanya pemikiran-pemikiran yang menolak Indonesia sebagai Negara Republik karena menganggapnya tidak bersumber dari Tuhan dan bahkan melabelinya dengan sistem taghut (syetan). ${ }^{116}$ Dan masih adanya beberapa wilayah yang ingin melepaskan diri dari kesatuan dalam negara Indonesia.Dalam keadaan demikian, sangat mungkin mengancam rasa nasionalisme dan mengganggu keutuhan dan persatuan bangsa Indonesia.

Dengan realitas masyarakat seperti di atas, penafsiran M. Quraish Shihab atas ayat-ayat yang mengandung arti kebangsaan dan nasionalisme, merupakan diantara jawaban dari problem masyarakat Indonesia saat ini, sehingga menyiratkan beberapa konsep nasionalisme, yakni sebuah tentang penyatuan masyarakat dan bangsa dalam suatu negara.

\footnotetext{
${ }^{116}$ Lihat misalnya tulisan Ihsan Tandjung yang berjudul "Berhala modern itu bernama Nasionalisme" dalam http://www.eramuslim.com/suara-langit/undangan-surga/berhala-modernitu-bernama-nasionalisme.htm diakses tanggal 02 April 2012.
} 


\section{B. Wawasan kebangsaan dalam al-Qur'an}

Dalam al-Qur'an tersirat mengenai wawasan tentang kebangsaan. Wawasan-wawasan tersebut menandakan adanya ajakan atau seruan untuk mentaatainya. Untuk menemukan wawasan kebangsaan dalam al-Quran para mufasir al-Qur'an mencoba mendekatinya dengan memahami kata-kata yang digunakan oleh al-Quran untuk mengungkapkan kata yang sepadan atau berdekatan dengannya. Sebagai salah satu mufasir al-Qur'an, Quraish Shihab dalam memahami tentang kebangsaan di dalam al-Qur'ann setidaknya menyinggung tiga term kata yang memiliki hubungan makna dengan istilah kebangsaan. Term-term tersebut adalah sya'b (QS Al-Hujurat(49): 13), qaum (QS Hud (11): 63, 64, 78, 84) dan ummah. ${ }^{117}$

Dalam kaitannya dengan kehidupan berbangsa, maka prinsip utama yang dapat menyatukan seluruh warganya adalah prinsip persamaan. Sebagaimana yang tetsebut dalam surat al-Hujurat ayat 11 di atas dinyatakan bahwa semua manusia sama dan dipandang sama dihadapan Allah. Hanya kadar ketaqwaannya yang membedakannya. Dalam konteks kenegaraan, prinsip ini merupakan tiang utama dalam negara. Tanpa prinsip ini negara akan goyah. Prinsip persamaan ini ditegaskan oleh Nabi ketika beliau berpdato setelah melaksanakan Haji Wada, "sesungguhnya leluhurmu adalah satu yaitu Adam. Karena itu tidak ada perbedaan antara orang Arab dan bukan Arab, antara yang berkulit merah dan berkulit hitam kecuali taqwanya kepada Allah". ${ }^{118}$ Dari penjelasan di atas, Quraish Shihab berpendapat bahwa paham kebangsaan adalah pengertian dari nasionalisme. ${ }^{119}$

\section{Gagasan-gagasan M. Quraish Shihab tentang Nasionalisme}

Dengan kondisi masyarakat Indonesia yang memiliki keyakinan yang beragam, telah membuka ruang dan peluang perdebatan (perbedaan pemahaman) di antara masyarakat di dalamnya. Perdebatan yang dimaksud tidak lain adalah

${ }^{117}$ M, Quraish Shihab, Wawasan al-Qur'an, Tafsir Maudhui atas Pelbagai Persoalan Bangsa, (Bandung: Mizan, 1996) cet-2 hlm.331.

${ }^{118}$ Bukhari, Shahih Bukhari, kitab al-Insan, hlm. 54

119 M. Quraish Shihab, Wawasan al-Qur'an, Tafsir Maudhui atas Pelbagai Persoalan Bangsa (Bandung, Mizan, 1996) cet-2, hlm. 330 
perdebatan tentang sistem kenegaraan Indonesia. Perdebatan tersebut telah dimulai sejak berdirinya Negara Indonesia, yakni pertentangan antara kaum nasionalis sekuler dan kaum agamawan yang ingin menjadikan negeri ini sebagai negeri berasaskan Islam formal. ${ }^{120}$ Bahkan, sampai sekarangpun masih ada pemikiranpemikiran yang menolak Indonesia sebagai Negara Republik karena menganggapnya tidak bersumber dari Tuhan dan bahkan melabelinya dengan sistem ţagut (syetan). ${ }^{121}$

Quraish Shihab di dalam tafsirnya al-Mishbah mencoba untuk menggali paham kebangsaan (nasionalisme) dengan berusaha menemukan prinsip-prinsip yang mendasari paham kebangsaan tersebut. Penelitian ini menunjukan bahwa alQur'an sebenarnya mengajari manusia untuk mencintai negara yang ditempatinya, meskipun mereka tinggal dengan berbagai macam kultur dan budaya. Hal tersebut dimaksudkan agar manusia bersatu tanpa ada perpecahan dan konflik di dalamnya. Karena keberagaman dalam kehidupan baik suku, budaya, bahasa, bahkan agama merupakan suatu keniscayaan (sunnatullah). ${ }^{122}$ Berikut gagasan-gagasan beliau tentang nasionalisme dalam tafsir Al-Mishbah

\section{Mencintai Negara}

Hal pertama yang harus dilakukan oleh seseorang dalam upaya untuk menciptakan rasa nasionalismenya adalah dengan mencintai negara di mana ia bertempat. Dan rasa nasionalisme itu tidak dapat dinyatakan adanya tanpa dibuktikan oleh patriotisme dan cinta tanah air. Rasa cinta tanah air atau nasionalisme dapat juga diartikan dengan rasa kebanggaan, rasa memiliki, rasa menghargai, rasa menghormati dan loyalitas yang dimiliki oleh setiap individu pada negara tempat ia tinggal. Cinta tanah air seseorang terhadap tempat di mana ia tinggali dapat tercermin dari perilaku seseorang dalam membela tanah airnya, menjaga dan melindungi tanah airnya, rela berkorban demi kepentingan bangsa

${ }^{120}$ Ahmad Syaf'I Ma'arif, Islam dan Pancasila Sebagai Dasar Negara: studi tentang perdebatan dalam konstituante, (Jakarta: Pustaka LP3ESIndonesia, 2006), hlm. 109

${ }^{121}$ Lihat misalnya tulisan Ihsan Tandjung yang berjudul "Berhala modern itu bernama Nasionalisme" dalam http://www.eramuslim.com/suara-langit/undangan-surga/berhala-modernitu-bernama-nasionalisme.htm diakses tanggal 02 April 2012.

${ }^{122}$ Q.S. Al-Maidah (5):48 
dan negaranya, mencintai adat atau budaya yang ada di negaranya serta ikut dengan melestarikan alam dan lingkungan.

Dengan demikian, seseorang yang memiliki rasa cinta pada tanah airnya akan berusaha dengan segala daya upaya yang dimilikinya untuk melindungi, menjaga kedaulatan, kehormatan dan segala apa yang dimiliki oleh negaranya. Rasa cinta tanah air inilah yang mendorong perilaku individu untuk membangun negaranya dengan penuh dedikasi. Oleh karena itu, rasa cinta tanah air perlu ditumbuhkembangkan dalam jiwa setiap individu yang menjadi warga dari sebuah negara atau bangsa agar tujuan hidup bersama dapat tercapai.

Rasa cinta terhadap tanah air di dalam al-Qur'an dapat dilihat dalam doa Nabi Ibrahim, tatkala ia berdoa untuk tempat tinggalnya yaitu Mekkah. Hal ini mencerminkan kecintaannya yang mendalam kepada tempat yang sedang ia tempati di kala itu.

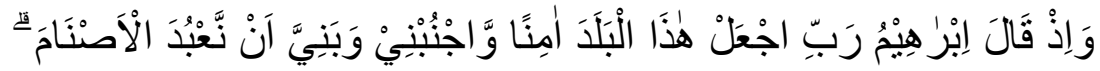

"Dan (ingatlah), ketika Ibrahim berkata: "Ya Tuhanku, Jadikanlah negeri ini (Mekah), negeri yang aman, dan jauhkanlah aku beserta anak cucuku daripada menyembah berhala-berhala". 123

Doa Nabi Ibrahim ini menggambarkan betapa ia cinta terhadap tanah airnya. Ayat ini tidak hanya sekedar bercerita tentang kisah Nabi Ibrahim dan Ismail, akan tetapi juga memberi kesan bahwa setiap orang haruslah mencintai negaranya serta sedapat mungkin menjaga keamanan dan kesejahteraan masyarakatnya.

Ayat lain yang juga menggambarkan tentang cinta terhadap negara adalah sebagai berikut: ${ }^{124}$

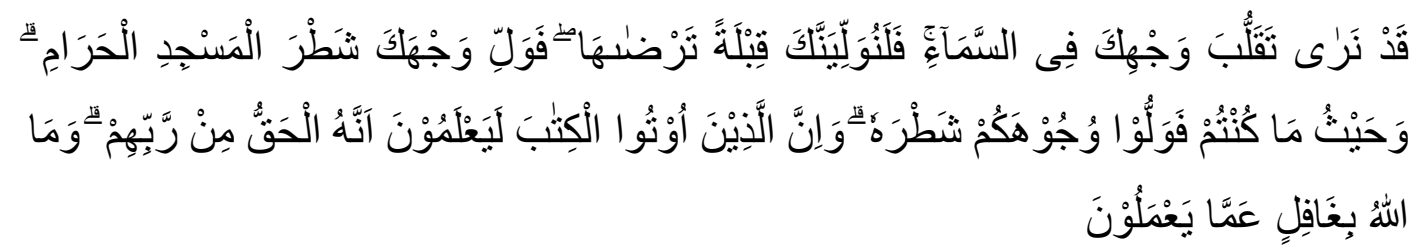

123 (Q.S Ibrahim (14):35

${ }^{124}$ Q.S al-Baqarah (02):144 
"Sungguh Kami (sering) melihat mukamu menengadah ke langit, Maka sungguh Kami akan memalingkan kamu ke kiblat yang kamu sukai. Palingkanlah mukamu ke arah Masjidil Haram”.

Di dalam ayat ini dapat dilihat bagaimana sikap Nabi yang berulang kali menengadahkan mukanya ke langit dengan menaruh penuh harapannya kepada Allah SWT. mengenai arah Kiblat yang diiginkannya. Hal ini merupakan ekspresi kecintaan yang sangat mendalam Nabi pada tanah Mekkah dan Ka'bah, yaitu tempat di mana Nabi lahir dan dibesarkan.

Di lihat dari asbab an-nuzulnya, Quraish Shihab menyatakan bahwa ayat ini menjelaskan tentang kegundahan hati Nabi Muhammad ketika ia diperintah berkiblat ke Baitul Maqdis dan mendapat respon yang kurang baik dari Kaum Yahudi. Melalui ayat ini, Allah mengungkapkan bahwa Dia mengetahui isi hati Nabi serta doa dan keinginannya agar kiblat dikembalikan lagi ke Ka'bah karena merupakan kiblat leluhurnya dan kebanggaan orang-orang Arab. ${ }^{125}$ Sehingga pada akhirnya Allah SWT. mengabulkan permohonannya.

Cinta Rasulullah kepada tanah tumpah darahnya tersebut juga tampak pula ketika beliau meninggalkan kota Makkah pada peristiwa hijrah, yaitu hijrah dari kota Mekah ke Madinah. Sambil menengok ke kota Makkah Rasulullah berucap:

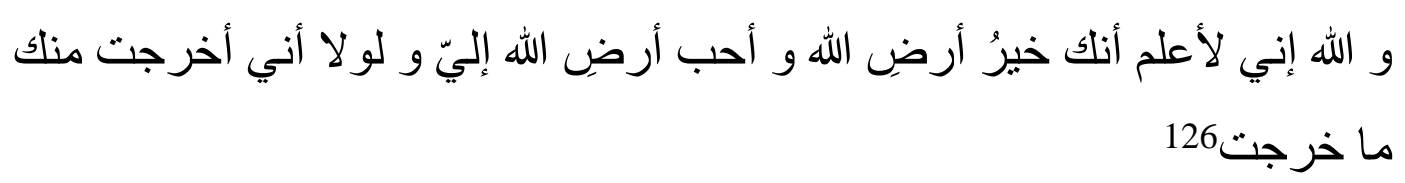

"Demi Allah, sesungguhnya engkau adalah bumi Allah yang paling baik dan paling aku cintai, seandainya saya tidak diusir dari sini, niscaya aku tidak akan meninggalkanmu”.

Jika melihat keadaan masyarakat bangsa Indonesia saat ini, maka rasa cinta terhadap bangsanya terbilang mulai surut. Hal tersebut terdapat banyak faktor yang menyebabkannya, sebagaimana yang telah dijelaskan dalam latar belakang hlm. 350 .

${ }^{125}$ M. Qurash Shihab, Tafsir al-Misbah, Pesan, kesan, dan keserasian al-Qur'an, vol. 1,

${ }^{126}$ Muhammad bin Abdillah Abu Abdillah al-Hakim al-Naisaburi, al-Mustadrak ala alSahihain (Beirut, Dar al-Kutub al-'Ilmiyyah, 1990), juz 3, hlm.315 hadis no. 5220. 
masalah yaitu adanya ketidakpuasan sebagian kalangan masyarakat dengan terhadap sistem pemerintahan Indonesia. Oleh sebabnya tahapan pertama yang mesti dilakukan oleh masyarakat demi kesatuan sebuah bangsa adalah cinta terhadap tanah air yang disertai dengan menjaganya dari segala macam ancaman yang dapat merusak keutuhan Indonesia

\section{Kesadaran Adanya Otoritas Pemimpin}

Sebuah Negara pasti mempunyai penguasa tertinggi yang bertugas untuk memimpin negaranya dalam upaya menjaga keberlangsungan negaranya, melindungi serta menjamin keamanan masyrakatnya. Karena itu, setiap warga haruslah sadar bahwa ada seorang yang sedang meminpinnya. Kesadaran tersebut menjadikan seseorang tidak arogan dalam melakukan sebuah tindakan, karena setiap segala bentuk tingkah lakunya harus sesuai dengan ketentuan-ketentuan yang telah berlaku di tempatnya dan itu telah disepakati oleh masyarakat dan disetujui oleh pemimpinnya. Dengan kesadaran itu pula, masyarakat yang dipimpinnya menjadi taat dan patuh terhadap hal-hal yang menjadi aturan dan kebijakkan pemimpin. Hal ini disebabkan seorang pemimpin ketika ia memberikan tuntunan, peraturan, dan kebijakan kepada masyrarakat yang dipimpinya tidak lain untuk kepentingan angota masyarakatnya secara menyeluruh. Demikian pula hanya dengan seorang pemimpin, ia diharapkan dapat menjalankan tugasnya dengan sebaik-baiknya dengan tidak didasarkan pada kepentingan pribadi ataupun kelompoknya.

Ayat yang menjadi landasan kewajiban warga negara untuk patuh dan taat terhadap pemimpin adalah sebagai berikut:

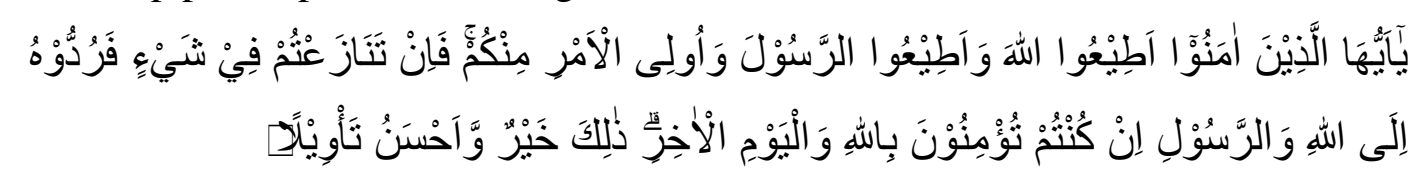

"Hai orang-orang yang beriman, taatilah Allah dan taatilah Rasul (Nya), dan ulil amri di antara kamu”. ${ }^{27}$

${ }^{127}$ Q.S al-Nisa' (4)]:59 
Kata kunci dari ayat ini adalah $u<l i l$ amr yang sering diartikan sebagai umara', ulama' dan ilmuan. Ibnu Asyur mengatakan bahwa $u<l i l$ amr adalah orang yang diangkat sebagai pejabat untuk mengurusi suatu hal yang dianggap penting. Misalnya para khalifah pengganti Rasul, para komandan perang, para fuqaha para sahabat, para mujtahid sampai para ilmuan masa kini. ${ }^{128}$

Quraish Shihab sendiri berpendapat bahwa kata ulil amr di atas adalah orang yang mewakili dari berbagai kelompok profesi yang berwenang mengangkat presiden, membuat undang-undang, dan hukum serta memperjuangkan kepentingan rakyat dan lain sebagainya. ${ }^{129}$ Secara keseluruhan dalam menafsirkan ayat di atas beliau mengatakan bahwa ayat tersebut berkaitan dengan munasabat ayat sebelumnya, yakni ayat yang berkaitan dengan amanah. Di situ beliau menjelaskan bahwa sesungguhnya Allah telah mewajibkan kepada manusia semua untuk melaksanakan dan menyampaikan amanah kepada seorang yang diamanatkan kepada kita, meskipun ia bukan orang muslim. Hal ini dapat dilihat dari segi asbab an-nuzul ayat tersebut. Yakni, suatu ketika pada zaman Rasulullah pintu Ka'bah dipegang oleh orang musrik. Rasulullah meminta kuncinya darinya untuk masuk ka'bah. Ketika Rasulullah keluar dari Ka'bah tersebut paman beliau yang seorang muslim meminta kunci tersebut dari Rasulullah dengan alasan pamanya ingin menjdi pemegang kunci Ka'bah, namun Rasulullah membacakan ayat tersebut. Karena seorang musrik tersebut adalah penjaga kunci Ka'bah yang telah diberi amanah oleh penduduk Mekkah sekalipun ia seorang non muslim.

Kesadaran terhadap otoritas pemimpin sangat perlu adanya. Oleh sebab itu, Rasulullah saw memerintahkan kepada umatnya untuk memilih pemerintah yang akan menangani urusan mereka dan dapat menjalankan amanat kepada mereka yang berhak menerimanya supaya mereka dapat bertindak dengan adil dalam memimpin rakyatnya. Berkaitan dengan ini, Ibnu Taimiyah memerintahkan rakyatnya untuk mentaati pemerintah selama pemerintah tersebut dalam keadaan

${ }^{128}$ Syaikh Muhammad Tahir bin 'Asyur, al-Tahrir wa al-Tanwir (Tunisia: Dar Sahnoun li al-Nasyr wa al-Taizi', 2007) Juz 5, hlm. 97. dalam software al-Maktab al-Syamilah al-Isdar al-Sani ${ }^{129}$ M. Qurash Shihab, Tafsir al-Misbah, Pesan, kesan, dan keserasian al-Qur'an, vol. 2, hlm. 486. 
taat kepada Allah. Bahkan dalam ruang lingkup kelompok yang kecil dan sedikit pun. ${ }^{130}$ Di dalam sebuah Hadis yang terdapat dalam Sunan Abu Dawud, yang diriwayatkan oleh Abu Hurairah, Rasulullah saw bersabda:

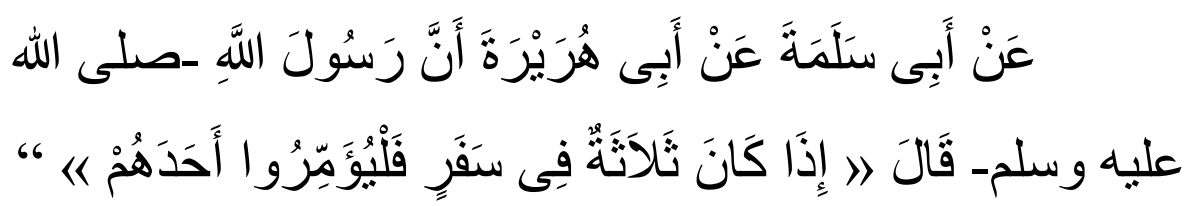

"Jika ada tiga orang keluar untuk bersafar, maka hendaklah mereka mengangkat salah di antaranya sebagai ketua rombongan. "131

\section{Persatuan Bangsa}

Gagasan Quraish Shihab selanjutnya mengenai nasionalisme adalah kewajiban bagi seluruh bangsa untuk bersatu dalam satu kesatuan. Setiap bangsa sudah barang tentu memiliki berbagai macam budaya, suku, bahasa, dan agama. Oleh sebab itu yang dimaksud dengan persatuan bangsa di sini adalah sikap yang mengedepankan satu misi nasional demi persatuan bangsa dan negara tanpa melihat berbagai perbedaan dan ego masing-masing kelompok.

Negara Indonesia yang memiliki kemajemukan sebagaimana yang tersebut di atas, adalah negara yang juga memiliki rasa persatuan yang kuat. Hal ini dapat dilihat pada sumpah pemuda dilaksanakan pada tanggal 28 Oktober $1928^{132}$, juga pada dasar ideologi negara yaitu pancasila, dan hukum konstitutinalnya yaitu Undang-undang dasar 1945 (UUD 1945). Dari Sumpah Pemuda pada kesepakatan dalam ketiga butirnya. Pada pancasila dituangkan dalam sila ketiga. Adapun dalam UUD 1945 bangsa Indonesia disatukan dalam satu wadah hukum yang hukum tersebut dapat menjamin nilai-nilai perdamaian, kerukunan serta keadilan seluruh warganya.

${ }^{130}$ Ibnu Taimiyah, Tugas Negara Menurut Islam terj. Arif Maftuhin Dzofir....., hlm.7

${ }^{131}$ HR. Abu Daud, Sunan Abu Dawud, no. 2611, juz 8, hlm. 55

132 "Kami putra putri Indonesia mengakui bertumpah darah satu, tanah air Indonesia. kami putra putrid Indonesia mengaku berbangsa satu, bangsa Indonesia. kami putra putrid Indonesia menjunjung bahasa persatuan, bahasa Indonesia". Sekretariat Menteri Muda Depdikbud, Hari Smupah Pemuda sekaligus Sebagai Hari Pemuda, (Jakarta: Depdikbud 1978), hlm. 3 
Dalam hal ini, bahwa Al-Quran juga memerintahkan persatuan dan kesatuan. Perintah tersebut dapat dilihat dari firmanNya dalam surat al-Mu'minun ayat 52 dan al-Anbiya' ayat 92:

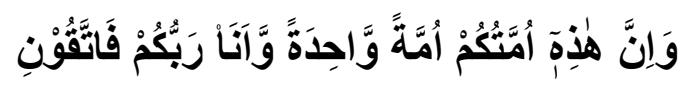

"Sesungguhnya (agama Tauhid) ini, adalah agama kamu semua, agama yang satu dan aku adalah Tuhanmu, Maka bertakwalah kepada-Ku”.

Dalam menafsirkan ayat di atas, Al-Raghib Al-Isfahani sebagaimana dikutip Quraish Shihab menjelaskan bahwa ummat adalah "kelompok yang dihimpun oleh sesuatu, baik persamaan agama, waktu, atau tempat, baik pengelompokan itu secara terpaksa maupun atas kehendak sendiri." Di sisi lain, di dalam Al-Quran ternyata ditemukan sembilan kali kata ummah yang digandengkan dengan kata wa<hidah, sebagai sifat umat. Tidak sekali pun AlQuran menggunakan istilah Wahdah Al-Ummah atau Tauhid Al-Ummah (Kesatuan/ penyatuan umat). Karena itu, menurut Quraish Shihab sungguh tepat analisis Mahmud Hamdi Zaqzuq, mantan Dekan Fakultas Ushuluddin Al-Azhar Mesir, yang disampaikan pada pertemuan Cendekiawan Muslim di Aljazair 1409 H/ 1988 M, bahwa Al-Quran menekankan sifat umat yang satu, dan bukan pada penyatuan umat, ini juga berarti bahwa yang pokok adalah persatuan, bukan penyatuan. ${ }^{133}$

Seiring dengan apa yang dikemukakan oleh Quraish Shihab di atas, upaya membangun kehidupan berbangsa dan bernegara atas landasan kebangsaan yang majemuk (plural) telah dipraktekkan Rasulullah dalam membangun negara Madinah. Sebagaimana diketahui, pemerintah Rasulullah saw di Madinah adalah pemerintahan yang dibangun di atas landasan penghargaan terhadap kebhinekaan agama, tradisi, dan suku. Penyatuan tersebuat dapat dilihat dengan tidak ada katakata Nabi yang menyinggung nama Islam atau berkeinginan mendirikan sebuah negara Islam. Akan tetapi, Nabi membangunnya berlandaskan kehendaknya untuk hlm. 334 .

${ }^{133}$ Quraish Shihab, Wawasan al-Qur'an, Tafsir Maudhui atas Pelbagai Persoalan Bangsa, 
persatuan masyarakat Madinah. Prinsip ini tertuang dengan jelas dalam naskah Konstitusi Negara Madinah yang dikenal luas dengan nama Piagam Madinah. ${ }^{134}$

\section{Menjaga Stabilitas Keamanan Negara}

Dalam upaya menjaga dan mempertahankan keutuhan negara Indonesia dalam cakupan yang lebih luas lagi, kesadaran adanya pemimpin yang mengatur suatu bangsa dan persatuan dari seluruh warga negara harus juga dibarengi dengan kesiapsiagaan dalam menghadapi ancaman dari luar bangsa yang berusaha memecah belah kesatuan bangsa Indonesia.

Salah satu ayat yang menyerukan kepada suatu bangsa agar bersiap siaga dalam upaya menjaga stabilitas keamanan negara. Allah berfirman:

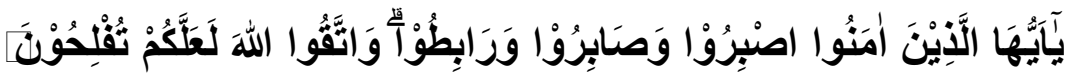

"Hai orang-orang yang beriman, bersabarlah kamu dan kuatkanlah kesabaranmu dan tetaplah bersiap siaga (di perbatasan negerimu) dan bertakwalah kepada Allah, supaya kamu beruntung". 135

Berkaitan dengan ayat ini, Quraish Shihab menjelaskan bahwa ayat ini berkaitan dengan kesabaran-kesabaran yang harus dimiliki oleh seorang muslim dalam hal apapun, baik dalam ibadah yang diperintahkan, seperti shalat, berbeda pendapat, memelihara persatuan dan kesatuan attaupun dalam berbagai musibah. Di sini kata wara<bithu< diartikan dengan kesabaran yang harus dimiliki oleh warga negara dalam hal pembelaan negaranya. ${ }^{136}$

Jika ayat ini dikontekstualisasikan di Indonesia, maka para aparat pemerintahanlah yang bertugas menjaga stabilitas keamanan negara. Para aparat TNI (Tentara Militer Indonesia) ditugaskan untuk menindak tindakan reprensif

134 Dalam butir pertama dari Piagam Madinah disebutkan bahwa penduduk Madinah adalah umat yang satu, lihat. J. Suyuti Pulungan, Prinsip-prinsip pemerintahan dalam piagam Madinah ditinjau dari pandangan al-Qur'an. (Jakarta: P.T RajaGrafindo Persada, 1996), hlm. 285

${ }^{135}$ Q.S Ali Imram (03):200

136 Quraish Shihab, Wawasan al-Qur'an, Tafsir Maudhui atas Pelbagai Persoalan Bangsa,,,,, hlm. 388. 
musuh dari luar sementara menindak tindakan reprensif musuh dari dalam yakni unsure warga masyarakat sendiri, dilakukan oleh aparat Kepolisian republic Indonesia (Polri).

Menjaga stabilitas negara di dalam ajaran Islam dapat disebut juga dengan konsep amar ma'ruf dan nahi munkar. Hal ini sebagaimana disabdakan Rasulullah saw:

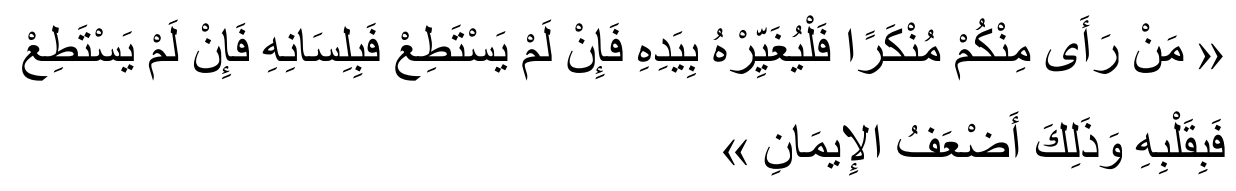

Barangsiapa yang melihat kemungkaran hendaklah mengubahnya dengan tangan; jika tidak mampu maka dengan lisan,; jika masih tidak mampu maka dengan hati. Dan itulah selemah-lemahnya iman. ${ }^{137}$

\section{Musyawarah}

Kata musyawarah dalam bahasa Arab berasal dari akar kata (شور) yang pada awalnya bermakna mengeluarkan madu dari sarang lebah. Makna ini kemudian berkembang sehingga mencangkup segala sesuatu yang dapat diambil atau dikeluarkan dari yang lain (termasuk pendapat). ${ }^{138}$ Hal yang sama juga diungkapkan oleh Waryono dalam bukunya "Tafsir Sosial". ${ }^{139}$ Jika demikian, maka lebah adalah para pemusyawarah, sedangkan madunya adalah hasil dari musyawarah (pendapat yang disepakati). Kata musyawarah sendiri dalam bahasa Indonesia merupakan serapan dari bahasa Arab yang mempunyai arti berunding atau berembuk. ${ }^{140}$

Di dalam al-Qur'an ada beberapa ayat yang menyerukan manusia agar bermusyawarah. Ayat-ayat tersebut di antaranya terdapat dalam Q.S 2:233, Q.S 3:158, Q.S 17:58, Q.S 6:57, Q.S 33:36. Quraish Shihab membagi musyawarah ke dalam dua wilayah Yaitu: Pertama: musyawarah dalam urusan yang berkaitan

137 Muslim, Shahih Muslim, Juz 1, hlm. 219 dalam sofwer Maktabah Syamilah

${ }^{138}$ M. Qurash Shihab, Tafsir al-Misbah, Pesan, Kesan, dan Keserasian al-Qur'an,,,, vol.

2, hlm. 312

${ }^{139}$ Wartono Abdul Ghafur, Tafsir Sosial, (Yogyakarta:Elsak Press, 2005), hlm. 153

140 Tim Penyusun Kamus Pusat, Pembinaan dan Pengembangan: Kamus Besar Bahasa Indonesia, (Jakarta: Balai Pustaka, 1987), hlm. 677 
dengan kehidupan bermasyarakat, dan kedua: musyawarah yang berkaitan dengan syariat. Oleh karenanya dalam menafsirkan ayat 158 surat al-Imran:

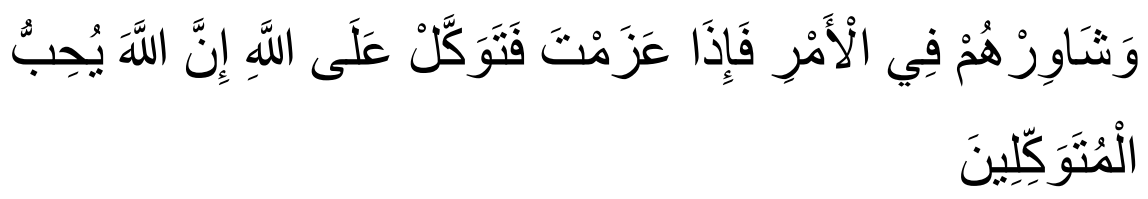

"Bermusyawarahlah kamu (Muhammad) dengan mereka dalam urusan tertentu. Kemudian apabila kamu telah membulatkan tekad, bertawakkalah kepada Allah Swt. Sesungguhnya Allah Swt mencintai orang-orang yang bertawakkal kepada-Nya".

Beliau menyatakan bahwa musyawarah yang dimaksud adalah musyawarah yang berkaitan dengan peperangan dan kehidupan dunia bukan urusan syariat atau agama. ${ }^{141}$ Ayat al-Qur'an yang memberi pengertian semacam ini juga dapat dilihat dalam ayat-ayat lainya, seperti:

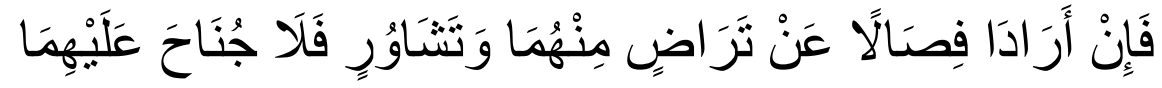

"Apabila suami-istri ingin menyapih anak mereka (sebelum dua tahun) atas dasar kerelaan dan musyawarah antar mereka, maka tidak ada dosa atas keduanya". ${ }^{142}$

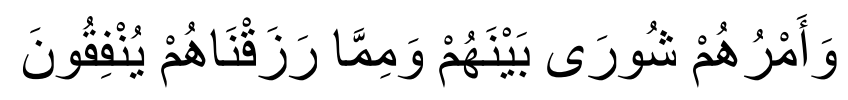

"Sedang urusan mereka (diputuskan) dengan musyawarat antara mereka; dan mereka menafkahkan sebagian dari rezki yang Kami berikan kepada mereka". ${ }^{143}$

Kedua ayat di atas menegaskan perlu adanya musyawarah untuk menghasilkan kesepakan bersama dalam urusan keluarga (pada ayat kedua) dan dalam bermasyarakat atau berorganisasi (ayat ketiga).

Adapun ayat-ayat musyawarah yang tercangkup dalam wilayah agama atau syariat antara lain terdapat dalam Q.S Al-Isra:85 ( tentang ruh), Q.S An2 , hlm. 310

${ }^{141}$ M. Qurash Shihab, Tafsir al-Misbah, Pesan, kesan, dan keserasian al-Qur'an,,,,, vol.

${ }^{142}$ Q.S al-Baqarah (2) : 233

${ }^{143}$ Q.S Al-Syura(42) : 38. 
Naziat:42 (hari kiamat), Q.S Al-An'am:57 dan Q.S Al-Ahzab:36. ${ }^{144}$ Ayat-ayat tersebut merupakan ayat-ayat yang hanya menjadi wewenang Allah dan Rasulnya semata, bukan urusan manusia dan tidak ada musyawarah yang dilakukan manusia di dalamnya. Karena itu, para sahabat tidak mengajukan saran menyangkut hal-hal yang telah mereka ketahui jika perkara tersebut datang dari Allah.

Melihat dari beberapa ayat al-Qur'an yang memerintakan manusia agar bermusyawarah, hal ini adalah sebagai sinyal bahwa prinsip musyawarah sangatlah penting untuk diamalkan terlebih lagi dalam konteks kehidupan bermasyarakat dan bernegara. Apabila melihat ke dalam konteks keindonesiaan, dengan masyarakatnya yang beragam dalam banyak hal, maka menurut penulis sistem pemerintahan yang sesuai dengan kondisi negara Indonesia adalah sistem permusyawarahan atau demokrasi. Karena dalam hal ini demokrasilah yang nilainilainya benyak mengadung unsur demokrasi, sebab segala norma dan dasar negara dihasilkan dari musyawarah. Hal ini dapat dilihat melalui sejarah panjang terbentuknya landasan dasar negara Indonesia yaitu Pancasila dan Undang-undang Dasar 1945.

Meskipun Syuro dalam Islam membenarkan keputusan pendapat mayoritas, hal itu tidak bersifat mutlak. Sebab keputusan pendapat mayoritas tidak boleh menindas keputusan minoritas, melainkan tetap harus memberikan ruang gerak bagi mereka yang minoritas. Lebih dari itu, dalam Islam suara mayoritas tidak boleh berseberangan dengan prinsip-prinsip dasar syariat.

\section{Adanya Kerjasama yang Baik antara Peminpin dengan Rakyatnya}

144 Q.S (6):57 “Katakanlah: "Sesungguhnya aku berada di atas hujjah yang nyata (Al Quran) dari Tuhanku, sedang kamu mendustakannya. Tidak ada padaku apa (azab) yang kamu minta supaya disegerakan kedatangannya. Menetapkan hukum itu hanyalah hak Allah. Dia menerangkan yang sebenarnya dan Dia Pemberi keputusan yang paling baik." Q.S (17):85 "Dan mereka bertanya kepadamu tentang roh. Katakanlah: "Roh itu termasuk urusan Tuhan-ku, dan tidaklah kamu diberi pengetahuan melainkan sedikit." M. Qurash Shihab, Tafsir al-Misbah, Pesan, kesan, dan keserasian al-Qur'an,,,, vol. 2, hlm. 310 
Suatu negara menjadi tidak stabil atau bahkan akan mengalami kehancuran manakala tidak ada kerjasama yang baik antara pemerintah (sebagai pengemban amanah rakyat) dengan rakyatnya. Oleh sebab itu, salah satu hal yang akan menjadikan suatu negara itu aman serta damai adalah terjalinya hubungan dan kerjasama yang baik dari pihak pemerintahan dengan masyarakat yang dipimpinya. Hal ini akan dirasa sangat menjadi kewajiban yang paling utama jika terjadi di negara sebesar Indonesia, yang mana segala hal dapat mengancam persatuan dan kesatuan Indonesia.

Seruan mengenai hal ini terdapat pada ayat berikut:

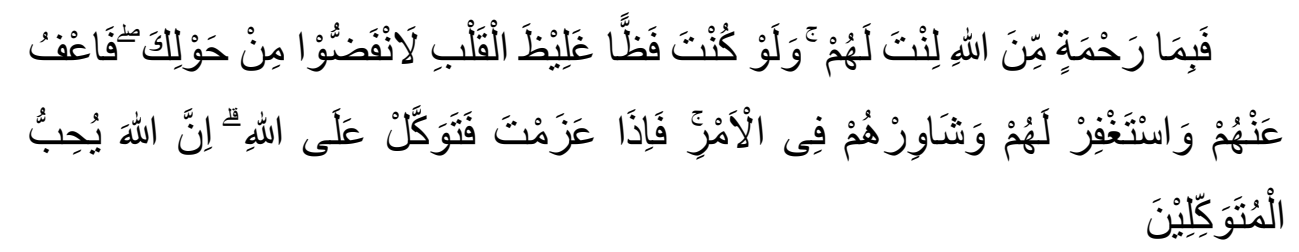

"Maka disebabkan rahmat dari Allah-lah kamu Berlaku lemah lembut terhadap mereka. Sekiranya kamu bersikap keras lagi berhati kasar, tentulah mereka menjauhkan diri dari sekelilingmu. karena itu ma'afkanlah mereka, mohonkanlah ampun bagi mereka, dan bermusyawaratlah dengan mereka dalam urusan itu. Kemudian apabila, engkau telah melembutkan tekad, bertawakllah kepada Allah. Sesungguhnya Allah mencintai orang-orang yang bertawakal". ${ }^{145}$

Ayat ini menjelaskan tentang etika dakwah Nabi dalam menghadapi masyarakat yang memiliki karakter yang berbeda-beda. Menurut Ibnu Asyur, dhamir lahum dalam ayat tersebut merujuk pada semua ummat bukan hanya dikhususkan pada orang-orang muslim di perang Uhud. Hal ini karena maqam tasyri'nya bukan hanya khusus orang-orang muslim saja tetapi untuk semua ummat sebagaimana disebutkan dalam ayat lain bahwa Rasul diutus untuk menjadi rahmat bagi semua orang di dunia (rahmatan lil alamin). Dan sebab sifat-sifat tersebutlah Nabi banyak mendapatkan simpatik dari orang-orang non-muslim yang kemudian masuk Islam. ${ }^{146}$

${ }^{145}$ Q.S surat Ali-imron (3) : 159.

${ }^{146}$ Syaikh Muhammad Tahir bin 'Asyur, al-Tahrir wa al-Tanwir, juz 4, hlm. 145. 
Sikap yang dilakukan oleh Nabi baik sebagai individu maupun sebagai peminpin Negara di Madinah. Rasulullah seringkali meminta pendapat kepada para sahabat dalam hal-hal strategi perang, pertanian, serta urusan-urusan lainnya yang menyangkut urusan keduniawiyahan. Sayyid Qutub dalam tafsirnya mengatakan bahwa ayat ini merupakan dalil qat'i yang menjelaskan bahwa Islam sejak permulaan perkembangannya telah mengakui musyawarah sebagai sistem pemerintahan. Sedangkan cara pembentukannya merupakan hal yang bisa berubah sesuai dengan perkembangan zaman. ${ }^{147}$ Namun, yang paling prinsip adalah adanya musyawarah antara peminpin dan yang dipimpin agar terjadi kerjasama yang baik antara masing-masing elemen sebuah bangsa guna menciptakan bangsa yang ideal.

Dalam hal kenegaraan pemerintah harus lebih meningkatkan kerjasamanya baik dalam bidang sosial, ekonomi, politik dan budaya dengan seluruh para menteri (penyalur aspirasi rakyat) atau aparat pemerintahan yang bersangkutan baik menuangkan segala pendapat dan pikirannya kemudian membulatkan tekad demi kemashlahatan dan persatuan bangsa Indonesia. Kerjasama di sini juga dapat diartikan sebagai tanggung jawab timbal balik antara pemimpin dan rakyatnya. Rakyat membuktikan tanggung jawabnya baik secara langsung atau tidak langsung untuk melakukan pengawasan terhadap kebijaksanaan pemerintah. Sebaliknya, ketaatan tersebut dapat menyadarkan pemerintah negara akan tanggung jawab dan amanah yang diembannya. Adapun hal-hal yang sangat perlu dikedepankan menuju kerjasama ini adalah sebagaimana yang tecantum dalam ayat tersebut yakni adanya sikap lemah lembut, memberi maaf dan membuka lembaran baru serta menjalankan hasil kerjasama tersebut dengan berserah diri kepada Allah SWT. Lemah lembut manakala seorang pemimpin dan rakyatnya tidak mengedepankan emosi, egois dan rasa ta'assub pada golongannya dari pada kemashlahatan yang menyeluruh. Memberi maaf kepada rakyat yang mungkin dilakukan oleh masyarakat tertentu sebelumnya sehingga mengawali kerjasa sama yang baru dengan lembaran yang baru pula. Dan dan terakhir

${ }^{147}$ Sayyid Qutub, Fi Zilal al-Qur'an, (Beirut: Dar Ihya' 1971), juz 1, hlm. 477 
membulatkan tekad untuk melaksanakan dan mengaplikasikan dari hasil kerjasa tersebut.

\section{Menghargai Perbedaan}

Bangsa yang besar tentunya tidak hanya menghargai tetapi juga melestarikan kebudayaannya. Bukan hanya dalam bentuk bahasa, suku dan agamanya yang beragam tapi juga adat istiadat yang merupakan sebuah budaya suatu bangsa. Bangsa Indonesia merupakan bangsa yang majemuk karena setiap warganya memiliki latar belakang etnis, kultur, dan agama yang berbeda-beda. Keanekaragaman tersebut terdapat di berbagai wilayah yang tersebar dari Sabang sampai Merauke. Setiap suku bangsa di Indonesia mempunyai kebiasaan hidup yang berbeda-beda. Kebiasaan hidup itu menjadi budaya serta ciri khas suku bangsa tertentu. Demi persatuan dan kesatuan, seharusnya kita menyadari dan menghargai keanekaragaman tersebut sehingga dapat menjadi satu bangsa yang tangguh. Dengan semboyan "Bhinneka Tunggal Ika", menjadikan keragaman suku bangsa dan budaya sebagai salah satu modal dasar dalam membangun Indonesia yang satu.

Dalam bahasa Arab adat istiadat dibahasakan dengan al-'Urf yang berarti adat kebiasaan yang berlaku dalam sebuah kelompok manusia. Kalimat al'Urf di dalam al-Qur'an secara langsung tercantum dalam surat al-A'raf:

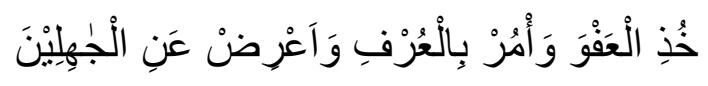

"Jadilah Engkau Pema'af dan suruhlah orang mengerjakan yang ma'ruf, serta berpalinglah dari pada orang-orang yang bodoh". ${ }^{448}$

Kata kunci dalam ayat ini adalah 'Urf. 'Urf adalah perbuatan baik atau adat kebiasaan yang berlaku dalam sebuah kelompok manusia. Dengan ayat ini, sebagian ulama seperti Malikiah berargumen bahwa hukum itu juga didasarkan pada kebiasaan yang berlaku dalam sebuah masyarakat. ${ }^{149}$ Sedangkan menurut Quraish Shihab, kata 'Urf sama dengan kata المعروف, yakni sesuatu yang dikenal

${ }^{148}$ Q.S al-A'raf (07) :199

${ }^{149}$ Ahmad bin Muhammad al-Syazili al-Fasi Abu al-Abbas, ,,,,, hlm. 595. 
dan dibenarkan oleh masyarakat, dengan kata lain adat istiadat yang didukung oleh nalar yang sehat serta tidak bertentangan dengan ajaran agama. Dan ini adalah adat istiadat yang jelas dan diketahui oleh semua orang serta diterima dengan baik oleh manusia-manusia normal. ${ }^{150}$

Dengan kata lain, al-'Urf yang dimaksud Quraish Shihab di sini adalah suatu kebiasaan dan adat istiadat yang dilakukan oleh masyarakat yang tidak bertentangan dengan al-khair, yakni prinsip-prinsip ajaran Islam. Rincian dan penjabaran kebaikan dapat beragam sesuai dengan kondisi dan situasi masyarakat. Sehingga, sangat mungkin suatu masyarakat berbeda pandangan dengan masyarakat lain. Namun, selama kebaikan itu tidak bertentangan dengan prinsip ajaran agama, maka itulah yang dinamai 'urf ma'ruf.

Berkaitan dengan adat kebiasaan Imam Bukhari sebagaimana dikutip Quraish Shihab dalam tafsirnya al-Mishbah meriwayatkan bahwa suatu ketika Aisyah mengawinkan seorang gadis yatim kerabatnya kepada seorang pemuda dari kelompok Anshar (penduduk kota Madinah). Nabi yang tidak mendengar nyanyian pada acara itu, kemudian Nabi berkata kepada Aisyah, "Apakah tidak ada permainan atau nyanyian ? Karena orang-orang Anshar senang mendengarkan nyanyian." ${ }^{151}$ Demikian, Nabi Saw. menghargai adat-kebiasaan masyarakat Anshar.

Dengan ingin memberikan "sesuatu" yang digemari kaum Anshar ini menunjukan bahwa bagaimana sikap Nabi yang sangat menghargai adat istiadat dari budaya kaum lain yang berbeda dengan adat kebiasaan Nabi sendiri. Sikap saling menghargai seperti yang dicontohkan oleh Nabi ini akan menjadi salah satu strategi pemerintah Indonesia dalam memupuk rasa nasionalisme seluruh rakyat Indonesia, jika pemerintah dapat menghargai keberagamaan adat istiadat rakyatnya serta melestarikannya, yakni melestarikan adat kebiasaan yang baik tentunya dan bukan sebaliknya, niscaya jiwa nasionalisme yang dimiliki oleh setiap warga akan bertambah dan semakin kuat.

${ }^{150}$ M. Qurash Shihab, Tafsir al-Misbah, Pesan, Kesan, dan Keserasian al-Qur'an,,,,, hlm. 429

151 Quraish Shihab, Wawasan al-Qur'an, Tafsir Maudhui atas Pelbagai Persoalan Bangsa,,,, hlm. 343. 


\section{Adanya Hukuman bagi Perusuh dan Pengacau Keamanan}

Dalam menjalankan sistem pemerintahannya, sebuah negara membentuk beberapa lembaga atau badan negara yang diciptakan sesuai dengan tugas, fungsi, peran, dan wewenang masing-masing berdasarkan bidangnya. Secara umum, tujuan akhir dari kesemua lembaga atau badan negara tersebut adalah tidak lain untuk mewujudkan cita-citanya. Sebagai contoh, cita-cita dan tujuan negara Indonesia telah dikemukakan dalam pembukaan Undang-undang Dasar 1945 (UUD 1945) ${ }^{152}$. Salah satu faktor yang berperan dalam mewujudkan tujuan negara tersebut adalah kebutuhan akan rasa aman.

Dalam Islam tujuan penjatuhan hukuman bagi perusak keamanan adalah pencegahan serta balasan ( $a r-r a$ 'du wa al-zahru), perbaikanan pengajaran pengajaran (al-Islah wa al-tahźib). ${ }^{153}$ Adapun pengertian dari pencegahan di sini adalah menahan pelaku agar tidak mengulang tindak pidana yang dilakukannya atau menahan orang lain untuk tidak melakukan tindak pidana yang sama dan menjauhkan diri dari tindak pidana tersebut. ${ }^{154}$ Sedangkan yang dimaksud dengan pembalasan adalah pembalasan, pidana hanya akan dijatuhkan kepada orang telah melakukan suatu tindak kejahatan. Dan hukuman tersebut harus ada sebagai balasan kepada pelaku tindak kejahatan atau pidana. ${ }^{155}$ Selain bertujuan mencegah dan balasan, pemberian hukuman juga bertujuan untuk mengusahakan perbaikan serta pengajaran bagi pelaku tindak kejahatan.

Secara langsung tuntunan akan adanya hukuman bagi para perusuh atau pengancam keamanan dalam suatu masyarakat tersebut telah tercantum dalam firman Allah SWT di dalam al-Qur'an.

152 “... untuk membentuk suatu pemerintahan negara Indonesia yang melindungi segenap segenap bangsa dan seluruh tumpah darah Indonesia dan untuk memajukan kesejahteraan umum dan mencerdaskan kehidupan bangsa, dan ikut mlaksanakan ketertiban dunia yang berdasarkan kemerdekaan, perdamaian abadi, dan keadilan sosial, maka disusunlah Kemerdekaan Kebangsaan Indonesia itu dalam suatu Undang-undang Dasar Negara Indonesia...”. Wardani, Kunthi Dyah, Impeachment Dalam Ketatanegaraan Indonesia, ,,,,,,hlm. 95

${ }^{153}$ Rahmat Hakim, Hukum Pidana Islam, (Bandung: Pustaka Setia, 2000), hlm. 63

${ }^{154}$ Ahmad Hanafi, Asas-asas Hukum Pidana Islam, (Jakarta:Bulan Bintang), hlm. 1967

${ }^{155}$ Rahmat Hakim, Hukum Pidana Islam,,,,, hlm. 63 


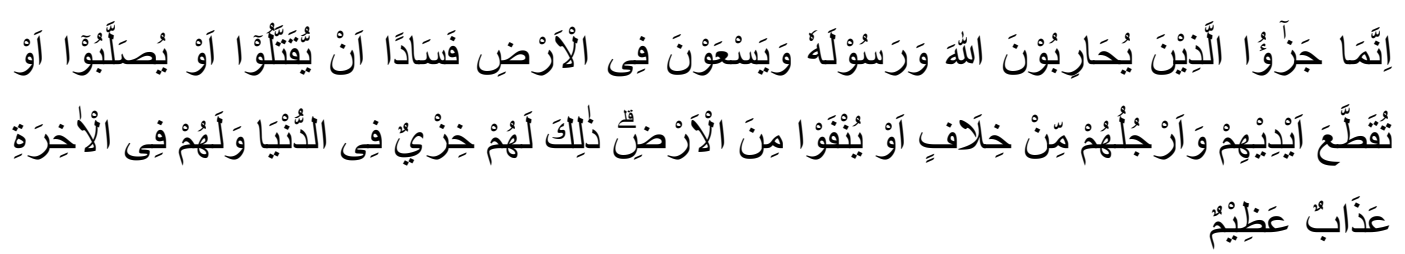

"Sesungguhnya pembalasan terhadap orang-orang yang memerangi Allah dan Rasul-Nya dan membuat kerusakan di muka bumi, hanyalah mereka dibunuh atau disalib, atau dipotong tangan dan kaki mereka dengan bertimbal balik, atau dibuang dari negeri (tempat kediamannya). yang demikian itu (sebagai) suatu penghinaan untuk mereka di dunia, dan di akhirat mereka beroleh siksaan yang besar. ${ }^{156}$

Dilhat dari asbab an-Nuzul nya ayat ini turun di Madinah di mana posisi Nabi sebagai peminpin tertinggi diberi kewenangan oleh Allah untuk menindak setiap orang yang suka membuat kerusuhan. M. Qurash Shihab menyatakan bahwa ayat di atas turun berkaitan dengan hukuman yang ditetapkan Nabi saw. dalam kasus suku al-Urainiyin. Dikisahkan bahwa sekelompok orang dari suku 'Ukal dan 'urainah datang menemui Nabi saw. dan menyatakan keislaman mereka. Setelahnya, mereka menceritakan tentang kehidupan mereka, maka Nabi memberI mereka sejumlah unta agar dapat mereka manfaatkan dengan meminum susu dan kencingnya. Di tengah jalan mereka membunuh pengembala unta itu, bahkan mereka murtad. Mendengar kejadian tersebut, Nabi mengutus pasukan berkuda yang berhasil menangkap mereka sebelum tiba di perkampungan mereka. Pasukan yang menangkap para perampok itu, memotong tangan dan kaki mereka, mencungkil mata mereka dengan besi yang dipanaskan kemudian ditahan hingga meninggal. ${ }^{157}$

Sayyid Qutb dalam tafsirnya fi zilali al-Qur'an mengatakan bahwa ayat di atas menerangkan sebagian hukum-hukum syariat dalam kehidupan manusia. Yakni hukum-hukum yang berkaitan dengan perlindungan jiwa dan kehidupan

\footnotetext{
${ }^{156}$ Q.S al-Maidah (5) : 33

${ }^{157}$ M. Qurash Shihab, Tafsir al-Misbah, Pesan, Kesan, dan Keserasian al-Qur'an,,,,, Vol.
} 3, hlm. 79 
manusia dalam bermasyarakat. ${ }^{158}$ Sebagaimana dipahami bahwa pengertian syariat Islam di sini adalah pemberlakuan hukum qisas bagi pelaku tindak pidana. Adapun tidak diberlakukannya hukum syariat Islam seperti dijelaskan Sayyid Qutb di berbagai negara seperti halnya di Indonesia bahwa Indonesia merupakan negara yang multi agama. Seperti hukuman qisas (hukuman mati) dalam syariat Islam bagi pelaku pembunuhan sengaja atau berencana, namun apabila mendapat maaf dari keluarganya maka dapat diganti menjadi diyah. ${ }^{159}$ Akan tetapi, dalam hukum pidana Indonesia pelaku pembunuhan berencana akan dihukum dengan penjara seumur hidup atau kurungan paling lama dua pulu tahun. ${ }^{160}$

Dengan demikian, penulis memahami bahwa paham kebangsaan juga diwujudkan dengan adanya peraturan/norma serta larangan yang harus dipatuhi oleh seluruh warga. Dengan demikian, keamanan akan terjamin dengan baik. Undang-undang Dasar (UUD) 45 dan KUHP dalam hal ini adalah aturan-aturan negara yang di dalamnya terdapat berbagai macam larangan dan perintah yang mesti dipatuhi oleh seluruh masyarakat Indonesia tanpa terkecuali.

\section{PENUTUP}

\section{Kesimpulan}

Dari pembahasan terdahulu sebagaimana terungkap dalam bab-bab yang ada dalam penelitian ini, maka dapat disimpulkan sebagai berikut:

Al-Qur'an merupakan petunjuk bagi seluruh umat manusia dalam menjalani kehidupannya, tidak hanya untuk meraih kehidupan yang kekal di akhirat kelak, akan tetapi juga dalam menata kehidupan manusia di dunia yang bermasyarakat dan bernegara.

Nasionalisme merupakan paham yang secara tidak langsung telah digambarkan oleh al-Qur'an al-Karim. Hal demikian dapat dibuktikan dengan

158 Sayyid Qutub, Fi Zilal al-Qur'an,,,,,,, hlm. 477

159 A. Djazuli, Fiqh Jinayat: Upaya Menanggulangi Kejahatan dalam Islam, ( Jakarta: Rajagrafindo Persada, 1997), hlm. 144-145.

${ }^{160}$ Pasal 340, KUHP: Kitab Undang-Undang Hukum Pidana/Indonesia, (s,n) (Yogyakarta, 1982) 
adanya terma-terma yang menunjukkan arti yang sama (atau mendekati sama) dengan kebangsaan, seperti kata sya'b, qaum, dan ummah. Ini menunjukan cinta terhadap tanah air sekaligus seruan untuk mencintai tanah kelahiran bagi para masyarakat di mana mereka bertempat. Dengan kata lain bahwa nasionalisme tidaklah bertentangan dengan dengan Islam. Sebab, al-Qur'an sendiri mengakui adanya konsep berbangsa dan suku-suku bangsa (syu'uba wa qaba 'il). Oleh karenanya, seorang pemimpin yang memimpin suatu bangsa atau negara yang masyarakatnya multikultural, maka pemimpin tersebut hendaknya berpaham nasionalis.

Adapun beberapa konsep M. Quraish Shihab terkait nasionalisme dalam tafsirnya al-Mishba<h adalah sebagai berikut: pertama, mencintai negara, kedua, kesadaran adanya otoritas pemimpin, ketiga, persatuan bangsa, keempat, menjaga stabilitas keamanan negara, kelima, sistem kenegaraan yang berdemokrasi, keenam, adanya kerjasama yang baik antara pemimpin dan rakyatnya, ketujuh, menghargai keberagaman baik adat, suku, maupun agama, dan kedelapan, adanya hukuman bagi perusuh dan pengacau keamanan.

Berkaitan dengan relevasi kedelapan konsep tersebut terhadap tatanan kehidupan mesyarakat negara Indonesia, maka konsep-konsep tersebut sangatlah relevan jika diterapkan ke dalam tatanan kehidupan negara Indonesia, karena selain kedelapan konsep tersebut merupakan poin-poin yang tersurat dalam al-Qur'an secara langsung, hal ini juga merupakan suatu ajaran dan tuntunan yang dipraktekkan oleh Nabi Muhammad saw sewaktu memimpin Negara Madinah yang juga dihuni oleh berbagai macam suku dan keyakinan sebagaimana yang tersirat secara jelas dalam Piagam Madinah. Maka, tatanan kehidupan seperti ini nantinya mampu memupuk rasa nasionalisme masyarakat Indonesia serta dapat menumbuh kembangkan rasa persatuan masyarakat Indonesia yang semakin terkikis oleh faktor-faktor baik internal maupun eksternal di atas.

Dengan mengemukakan beberapa ayat di dalam al-Qur'an yang mengandung makna nasionalisme di atas, penulis semakin yakin bahwa masyarakat 
Indonesia sudah seharusnya memiliki sikap nasionalisme yang kuat di setiap wilayah yang ditempatinya. Dengan gagasan-gagasan itu pula nantinya akan menjadi sebuah jawaban dan solusi dari berbagai macam faktor baik eksternal maupun internal yang semakin mengikis rasa nasionalisme, persatuan dan kesatuan rakyat Indonesia. Sehingga dengan ini pula masyarakat dapat memahami pentingnya persatuan dan kesadaran masyarakat dalam negara kesatuan republik Indonesia yang saling menghargai berbagai macam keberagaman Indonesia tanpa pengucilan dan pengkhususan terhadap satu golongan maupun golongan tertentu.

\section{Saran}

Berkaitan dengan penelitian ini ada beberapa saran yang perlu penulis sampaikan, yaitu:

Pertama, persoalan-persoalan tentang nasionalisme dapat diteliti lebih mendalam lagi, yakni suatu penelitian yang lebih melibatkan berbagai macam segi/bidang. Hal ini disebabkan penulis dalam penelitian ini masih bersifat kajian tentang nasionalisme secara umum dalam kaitannya negara Indonesia. Kedua, arag penelitian tentang nasionalisme ini mendapatkan hasil yang lebih, maka penulis juga menyarannkan untuk penelitian selanjutnya dapat membandingkan dengan tokoh mufasir lain, baik tokoh mufasir dalam maupun luar negara Indonesia. Hal ini karena penulis hanya mengkaji persoalan ini dengan kajian terbatas pada satu tokoh tafsir al-Qur'an.

\section{E. Daftar Pustaka}

Agil, Husain Al Munawar, Said. Fikih Hubungan Antar Agama. 2005. PT Ciputat Press:Ciputat. 
al-Qardawi, Yusuf, Zhahirah al-Ghuluw fi al-Tafkir, (Kairo: Maktabah Wahbah, 1990)

Al-Bukhari, Abu Abdillah, al-Jami’ al-Sahih al-Mukhtasar, Beirut: Dar Ibnu Kasir, 1987.

Anwar, Kamus Lengkap Bahasa Indonesia (Surabaya: Amelia Surabaya, 2003)

Al-Banna, Gamal. Al-Ta'adudiyah fi al-Mujtama' al-Islami, (Kairo: Dar al-Fikr al-Islami, 2001)

Alwi Shihab, Isalm Inklusif: Menuju Sikap Terbuka dalam Beragama, Bandung:Mizan, 1998,

Badran, Badran Abu Al-'Aynain, Al-Alaqah al-Ijtimaiyah bayn al-Muslimin wa

Ghayr alMuslimin. (Iskandariyah: Mu'assanah Shabab al-Jami’ah, 1984)

Coward, Pluralisme dan Tantangan Agama-agama, (Yogyakarta: Kanisius 1989).

Ismail, Faisal. Islam Idealitas Ilahiyah dan Realitas Insaniyah.1999.PT Tiara Wacana Yogya: Kopen-Banteng.

Knitter, Paul F. Satu Bumi Banyak Agama.1995. PT BPK Gunung Mulia. Jakarta

Qutb, Sayyid. Fi Zilalil Qur'an, Kairo: Dar al-Shuruq, 2003

Tabataba’i, Muhammad Husayn. Al-Mizan Fi Tafsir Al-Qur'an, Beirut:

Muassasahal-A'lam alMatbu'at, 1991

Shihab M. Qurash, Tafsir al-Misbah: Pesan, Kesan, dan Keserasian al-Qur'an Jakarta: Lentera Hati 2003 .

Shihab, M. Quraish, Membumikan Al-Qur'an: Fungsi da Peran Wahyu dalam Kehidupan Bermasyarakat, Cet. XXII, (Bandung: Mizan, 2001)

, Wawasan al-Qur'an: Tafsir Maudlu'i atas Pelbagai

Persoalan Umat, (Bandung: Mizan, 1999)

Wawasan al-Qur'an, Tafsir Maudhui atas Pelbagai

Persoalan Bangsa, (Bandung, Mizan, 1996) 
Tafsir al-Misbah, Pesan, kesan, dan keserasian al-Qur'an,

(Tangerang: Lentera Hati, 2007)

Membumikan al-Qur'an; Fungsi dan Kedudukan Wahyu

dalam Kehidupan Masyarakat (Bandung: Mizan, 1994)

Lentera Hati; Kisah dan Hikmah Kehidupan (Bandung:

Mizan, 1994)

, Secercah Cahaya Ilahi; Hidup Bersama Al-Qur'an

(Bandung; Mizan, 1999)

Hidangan Ilahi, Tafsir Ayat-ayat Tahlili (Jakarta: Lentara

Hati, 1999)

, Jalan Menuju Keabadian (Jakarta: Lentera Hati, 2000)

Al-Qur'ân dan Maknanya; (Jakarta: Lentera Hati, Agustus

2010)

Tafsîr Al-Lubâb; Makna, Tujuan, dan Pelajaran dari SurahSurah Al-Qur'ân (Boxset terdiri dari 4 buku) (Jakarta: Lentera Hati, Juli 2012) 